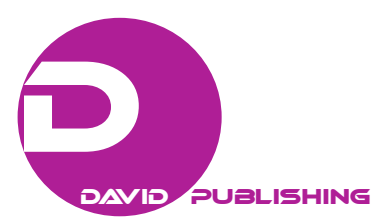

\title{
Testing the Hypothesis of J Curve for Turkish Economy*
}

\author{
Süreyya Y1lmaz \\ Çă̆ University, Yenice, Mersin, Turkey \\ İbrahim Özaytürk, Gürçem Oransay \\ Çukurova University, Adana, Turkey
}

\begin{abstract}
The purpose of this paper is to find the relationship between balance of foreign trade and real exchange rate in econometrics concept by using time series method. The authors used annual data of foreign trade deficit, real exchange rate, gross domestic product (GDP) of Turkey from 1989 to 2014, and analyzed the long-term relation of them by using ARDL bound testing method. By the result of test method; although there was a long-term relationship between balance of foreign trade, real exchange rate, GDP of Turkey and of the world, the coefficient of real exchange rate was insignificant in terms of statistical methods. Turkey and the world as well as being statistically significant coefficient of GDP, it was concluded that there was significant relationship with the economic aspects.
\end{abstract}

Keywords: foreign trade deficit, real exchange rate, J curve effect, ARDL bound test

\section{Introduction}

The effect of increasing of instability of exchange rate on foreign trade balance has been the reason of attracting attention of economists after Bretton Woods collapsed. This effect is also widely used in research papers by economists. However, there was no any consensus about the direction of this effect. Although there were lots of research papers for a negative effect of increasing of instability of exchange rate on foreign trade (Wilson, 2001; Kızıltan \& Ciğerlioğlu, 2008; Coşkun \& Taylan, 2009), many research papers proved that it is not certain (Arize, 1994; Bahmani-Oskooee \& Alse, 1994; Onafowora, 2003; A. Kasman \& S. Kasman, 2005; Brada, Kutan, \& Zhou, 2005; Karaçor \& Gerçekler, 2012; Aral, 2015). Furthermore, several research papers reached some finding that there is no any significant relationship between instability of exchange rate and balance of foreign trade (Zengin \& Terzi, 1995; Sivri \& Usta, 2001; Yamak \& Korkmaz, 2005; Karagöz \& Doğan, 2005; Yılmaz \& Kaya, 2007; Aktaş, 2010).

As seen on previous research papers, there is no any consensus among researchers to understand the interaction of exchange rate and balance of foreign trade on different periods. The similar things may say for different countries based on same subject. At this point, the purpose of this paper is to make an analysis of the effect of instability of exchange rate on foreign trade. The first section has correlated with this effect based on related hypothesis. The second section is related to some other researches which are in literatures and their

\footnotetext{
* This article was presented on International Cogress of Management, Economy and Policy in 2016.

Süreyya Yılmaz, research assistant, International Banking and Finance, Çă̆ University, Yenice, Mersin, Turkey.

İbrahim Özaytürk, Ph.D. student, Economics, Çukurova University, Adana, Turkey.

Gürçem Oransay, research assistant, Economics, Çukurova University, Adana, Turkey.

Correspondence concerning this article should be addressed to Süreyya Y1lmaz, International Banking and Finance, Çukurova University, Yasar Baybogan Campus, Adana-Mersin Highway, Yenice 33800, Turkey.
} 
empirical results. The following sections talk about the data set of research and econometrics process with the results.

\section{Hypothesis of J-Curve}

$\mathrm{J}$ curve hypothesis is described by economists as interpretation of changes in the balance of foreign trade and changes in the value of national currency at the same time. By J Curve Hypothesis, after an increase in the exchange rate and devaluation in the money market, the fluctuation experienced in the foreign trade balance is in the form of deterioration first and recovery afterward. Yet, deterioration-recovery will have drawn in form of " $J$ " letter. The reason of this is lowering of the short-term elasticity and the short-term flexibility doesn't meet the Marshall-Lerner condition. Yet, the producer and consumers could need some time to accommodate to new case since there is an increase in exchange rate.

Furthermore, the $\mathrm{J}$ curve hypothesis could interpret as high impact on income effect in short term and high impact on price effect in long term (Yamak \& Korkmaz, 2005). In this context, those countries in the devaluation process have to make all preparations in order to reduce domestic price before their devaluation decision is made. Monetary value losses after the current account deficit increased will help to balance in the current deficit after a certain period of time. Thus, this all way to reach the balance will remind of J letter (Uzunoğlu \& Alptekin, 2009). Exporters who are in the country that has a devaluation process also could be reason to increase their prices because of an increase in demand. At the same time, workers who work in

exporting firms may demand higher wages and thus increase the cost for firms, which in turn can lead to higher prices due to higher labor costs (Caves, Jeffrey, \& Ronald, 2007). All these cases could be reason for economy as a threat to the positive reflection of the devaluation on exports.

\section{Literature}

Onafowora (2003) conducted a study on Indonesian, Malaysian, and Thai whose economies are devalued East Asian economies since the mid-1990s for the period 1980-2001. Onafowora tested whether these countries have a critical flexibility in commercial relations with Japan and the United States.

According to the results obtained by Onafowora, in relation to real exchange rate-trade balance; $\mathrm{J}$ curve hypothesis is valid for Indonesia-US, Indonesia-Japan, Malaysia-US, Malaysia-Japan, Thailand-US.

In the case of Thailand-Japan relations, it is observed that the trade balance of shock, which occurred in the real exchange rate, initially recovered, then worsened, and finally recovered again. In this case, it is emphasized that the $\mathrm{J}$ curve can be explained by the $\mathrm{S}$ curve hypothesis.

Baek (2007) reached the conclusion by using the data for the study of US and Canada for the period 1989-2005, America's trade with Canada is very rarely affected by the J curve. Bahmani-Oskooee and Brooks (1999) also examined American's trade with its trade partner (Canada, France, Germany, Italy, Japan, England) for the period 1973-1996 by using the data. According to the analysis made, there was no any result to support the $\mathrm{J}$ curve effect in the short term.

In the study of Hsing (2005), the partnership with Japan, Korea, Taiwan, and America and the rest of the world has been studied for the period 1980-2001. By the result of analysis, only Japan has a relationship with its partner in terms of J curve. By Narayan's (2004) study, analysis of New Zealand for the period of 1970-2000 showed that the J curve effect is valid for New Zealand. According to Zhang's (1996) analysis of China's study for the period of 1991-1996, the effect of the J curve is not the result for China. 
According to the results of the analysis conducted by Terzi and Zengin (1999), which was made for the period of 1989-1996, the result of J curve is not valid for Turkey. Köse, Ay, and Topallı (2008) studied on the data of 1995-2008 period that belong to Turkey, they reached that the effect of J curve is not valid for Turkey. In a similar study by Karamelikli (2016), quarterly and monthly data of Turkey for the period of 2003-2015 are examined and have found no evidence of cointegration between the quarterly period data of Turkey and the curvilinear effect of the J curve.

If the monthly data are taken into account for the study, while the existence of the cointegration relation can be mentioned, the $\mathrm{J}$ curve effect is not observed. According to research that is made by Kösekahyaoğlu and Kemeç (2015) for the period 1997-2013 it has resulted that the J curve hypothesis is not valid for Turkey. On the other hand, Akbostancı (2004) conducted a study with data which covered the period of 1987-2004, and according to the analysis, Turkey is in conformity with the behavior of S curve rather than the effect of $\mathrm{J}$ curve. As a result of the researches for the J-curve, no consensus was reached on it and opposing views emerged for $\mathrm{J}$ curve. Some researchers have achieved results on the validity of the $\mathrm{J}$ curve hypothesis, but some have not found similar results. Although varying according to the country group studied, the periods examined, and the diversity of the variables, these differences still remain of interest for researchers.

\section{Model and Data Set}

The purpose of this study is aimed to examine the effects of real exchange rate changes on foreign trade deficit. Annual data and time series methods for the period of 1989-2014 were used for Turkey in this study. Variables in practice: Gross Domestic Product of Turkey (TGDP), Gross Domestic Product of World (WGDP), Real Exchange Rate (RER), Import Value of Turkey (M), and Export Value of Turkey (X). The foreign trade deficit was achieved by subtracting the total imports and exports from total imports after the revaluation of the import and export unit value index. All data are expressed in US dollars and in scale units and have been converted into "billion dollars". The data are based on year of 2005 and there is no need for a method of eliminating seasonal effects since annual data are studied. Data have been collected from: the World Bank, the Central Bank of the Republic of Turkey, Electronic Data Distribution System (EVDS), the Turkish Statistical Institute (TURKSTAT), and the Ministry of Development. All analyses and estimations in the study were also made by using Eviews 9.0 and Microfit 5.0 package program.

The study examines the effects of real exchange rate changes on international trade balance, which are very important for foreign trade; an increase in real exchange rate for Turkey caused whether any improvement in foreign trade balance was researched. As a matter of fact, an increase in the real exchange rate (depreciation of the domestic currency) may cause the prices of domestic goods to decrease relatively, which may lead to an increase in the exports of the country due to the increase of external demand for domestic goods (Mishkin, 2004; Felderer \& Homburg, 2010). The model that Rose and Yellen (1989) used in the study is a guide to examine the mentioned effect. By this model,

$$
D T A=D T A\left(R E R, Y_{\mathrm{TGDP}}, Y_{\mathrm{WGDP}}\right)
$$

In this model, "DTA" stands for foreign trade deficit, "RER" real exchange rate, "Y TGDP" refers to Gross Domestic Product of Turkey, and "Y WGDP" Gross Domestic Product of World. 


\section{Econometric Approach}

In the time series analysis, it is important that the series are stationary. The reason for this is that non-stationary series cause fake regression. The relevance of the result of the regression is very strong in relation to whether the series is stationary or not (Gujarati, 2004). In the time series, it is easy to stabilize the series by using the logarithm taking method which is used to stabilize the variables. Therefore, the logarithms of the variables are taken and " $\operatorname{Ln}(M-X)$ " instead of " $M-X$ ", "LnRER" instead of "RER" which represents the real exchange rate, " $L n\left(T_{G D P}\right)$ " instead of " $T_{G D P}$ " which expresses the gross domestic product of Turkey, and finally " $\operatorname{Ln}\left(W_{G D P}\right)$ " which represents the gross domestic product of the world instead of " $W_{G D P}$ " is used.

Thus, ADF and KPSS Unit Root Test were used in the analysis part of the study, and ARDL Boundary Test Approach and Uncorrected Error Correction Model were used later on. In the ongoing part of the study, these methods will be mentioned and the results of the analysis will be mentioned as well.

\section{Unit Root Test}

The most commonly used methods for testing the stationary feature of the series are the KPSS tests, developed by Dickey and Fuller (1979), Augmented Dickey-Fuller (ADF), Phillips and Perron (1988), and Kwiatkowski, Phillips, Schmidt, and Shin (1992). In this study, the stability of the series was investigated by using the ADF unit root test and the KPSS unit root test. The Akaike Information Criteria (AIC) is used to determine the delay length. The results of the analysis are given in Table 1 below.

Table 1

\section{ADF and KPSS Unit Root Test}

\begin{tabular}{|c|c|c|c|c|c|}
\hline \multirow{2}{*}{ Variables } & \multicolumn{3}{|c|}{$\mathrm{ADF}$} & \multicolumn{2}{|r|}{ KPSS } \\
\hline & Intercept & Intercept and trend & None & Intercept & Intercept and trend \\
\hline $\operatorname{Ln}(\mathrm{M}-\mathrm{X})$ & $-2.64^{*}[0]$ & $-4.88^{* * *}[0]$ & $1.05[1]$ & $0.70^{* *}$ & 0.07 \\
\hline LnRER & $-1.61[0]$ & $-2.38[0]$ & $0.82[0]$ & $0.66^{* *}$ & 0.09 \\
\hline $\operatorname{Ln}\left(\mathrm{T}_{\mathrm{GDP}}\right)$ & $-0.48[0]$ & $-2.91[0]$ & $4.28^{* * *}[0]$ & $0.75^{* * *}$ & 0.07 \\
\hline $\operatorname{Ln}\left(\mathrm{W}_{\mathrm{GDP}}\right)$ & $-0.39[0]$ & $-1.80[0]$ & $10.0[0]$ & $0.75^{* * *}$ & 0.10 \\
\hline \multicolumn{6}{|c|}{ Critical values } \\
\hline $1 \%\left(^{* * *}\right)$ & -3.72 & -4.37 & -2.66 & 0.73 & 0.21 \\
\hline $5 \%\left(^{* *}\right)$ & -2.98 & -3.60 & -1.95 & 0.46 & 0.14 \\
\hline $10 \%\left(^{*}\right)$ & -2.63 & -3.23 & -1.60 & 0.34 & 0.11 \\
\hline
\end{tabular}

Notes. Values in square brackets indicate the delay lengths which are determined by the AIC of the variables; ${ }^{*},{ }^{* *},{ }^{* * *}$ these stars show us the significant level of $1 \%, 5 \%, 10 \%$.

The empty and alternative hypothesis for the ADF Unit root test is as follows;

$\mathrm{H}_{0}$ : Series is not stable (with unit root).

$\mathrm{H}_{1}$ : Series is stable (without unit root).

In order for the absolute value of the ADF- $t$ statistic to be significant at the $5 \%$ level, these values should be larger than Mac-Kinnon critical values as absolute values. As in Table 1, level values of the dependent variable "Ln(M-X)" are not larger than the Mac-Kinnon critical value as an absolute value, so that series are not static. The other variables except for $\operatorname{Ln}\left(\mathrm{T}_{\mathrm{GDP}}\right)$ are larger than Mac-Kinnon critical value in terms of absolute value and the $\mathrm{H}_{0}$ hypothesis is rejected by this value. Thus, it can be said that these are stationary when 
the first differences of the independent variables are taken.

Kwiatkowski et al. (1992) proposed a Lagrange Multiplier (LM) statistic method for stationary basic hypothesis testing. That hypothesis is the alternative hypothesis which has series and these series are not stationary. Accordingly, unit root and stationary tests are complementary to each other. The hypothesis of stationary test is described as KPSS in literature:

$\mathrm{H}_{0}$ : Series is stable (without unit root).

$\mathrm{H}_{1}$ : Series is not stable (with unit root).

If the calculated LM value is smaller than the critical values, the basic hypothesis $\mathrm{H}_{0}$ is accepted. In the opposite case, $\mathrm{H}_{1}$ is rejected. When the series are examined, it is seen that the variables reject the $\mathrm{H}_{0}$ hypothesis in the fixed term. However, it is seen that all variables accept the $\mathrm{H}_{0}$ hypothesis in the fixed and trend terms. According to the result of ADF and KPSS Unit Root Tests, the stability ratios of the variables are different and this difference allows the study to continue with the ARDL boundary test approach. This approach examines the cointegration relationship between the variables with different stagnation degrees.

\section{ARDL Approach}

Johansen (1988) states that variables have to be stable in order for cointegration analysis to be possible. As a result of the unit root test, it was observed that the series were not stable at the same order. For this reason, the Autoregressive Distributed Lag (ARDL) boundary test approach developed by Pesaran, Shin, and Smith (2001) was used in case that the degrees of stability of the series are different for the cointegration analysis.

In this context, the number of delays must be determined before the boundary test is applied. The appropriate delay length was used in the Vector Sequential Distribution Model (VAR) in the analysis, and the Akaike Information Criteria (AIC), Schwarz Criteria (SC), and Hannan Quinn Criteria (HQ) were taken into account. Accordingly, the appropriate delay length according to AIC, SC, and HQ is set to "2".

While the existence of the cointegration relation is examining, the first time delays of dependent and independent variables are examined by the $\mathrm{F}$ statistic. This testing hypothesis is such as $H_{0}=\alpha_{1}=\alpha_{2}=\alpha_{3}=\alpha_{4}$ $=0$. At the table that prepared by Pesaran et al. (2001), if the computed $f$ value is greater than the upper critical value, the null hypothesis " $\mathrm{H}_{0}$ : Serial is not co-integrated" is rejected, the alternative hypothesis " $\mathrm{H}_{1}$ : Serial is co-integration" is accepted. According to the analysis result shown in Table 2, $\mathrm{H}_{1}$ hypothesis (10\%) was accepted for the series. At the same time, it has been deemed appropriate to analyze the series with different delays of the series to determine the existence of a long- and short-term relationship between the series.

Table 2

F Statistical Results for Long-Term Relations Existence

\begin{tabular}{llll}
\hline$F$ value & \multicolumn{3}{c}{ Critical values at significance level } \\
\hline & & Lower limit & Upper limit \\
5.0558 & $5 \%$ & 3.9223 & 5.3082 \\
& $10 \%$ & 3.1217 & 4.3232 \\
\hline $\mathrm{R}^{2}=0.96$ & $\mathrm{~F}$ ist. $=0.65(0.00)$ & & $\mathrm{DW}=2.1507$ \\
Diagnostic tests & $T$-value & & $P$-value \\
Autocorrelation test & 0.446 & 0.54 & 0.97 \\
Changing variance test & 0.846 & & \\
\hline
\end{tabular}


As shown in Table 2, the calculated F-statistic is around 10\%. The upper critical value level of $\mathrm{F}$ that was published by Pesaran et al. (2001) indicates the presence of a cointegration relationship. Moreover, it shows that there will be no false regression problem in the analysis to be made with the level values of the variables. There is no need for autocorrelation problems to implement the ARDL model and as seen in Table 2, there is no autocorrelation problem in the series.

\section{Long-Term Relationship: ARDL Bounding Testing Approximation}

For determining relationship of short and long term, ARDL bounding testing is recreated according to different delay lengths. In conclusion of analysis which is determined as maximum delay length is one according to SC, estimating ARDL $(1,2,2,0)$ model is decided. Conclusion of ARDL $(1,2,2,0)$ model and long-term coefficients is in below table.

Table 3

Conclusion of ARDL (1, 2, 2, 0) Model and Calculated Long-Term Coefficients

\begin{tabular}{lllll}
\hline Variables & Coefficient & S. D. & $T$-value & $P$-value \\
\hline $\mathrm{C}$ & 14.206 & 4.730 & 3.002 & $(0.009)$ \\
$\mathrm{Ln}(\mathrm{M}-\mathrm{X})(-1)$ & 0.401 & 0.158 & 2.543 & $(0.023)$ \\
$\mathrm{Ln}(\mathrm{RER})$ & 0.793 & 0.273 & 2.897 & $(0.011)$ \\
$\mathrm{Ln}(\mathrm{RER})(-1)$ & -0.261 & 0.366 & -0.712 & $(0.487)$ \\
$\mathrm{Ln}(\mathrm{RER})(-2)$ & -0.728 & 0.313 & -2.323 & $(0.035)$ \\
$\mathrm{Ln}\left(\mathrm{T}_{\mathrm{GDP}}\right)$ & 6.128 & 0.620 & 9.882 & $(0.000)$ \\
$\mathrm{Ln}\left(\mathrm{T}_{\mathrm{GDP}}\right)(-1)$ & -5.085 & 1.210 & 4.201 & $(0.001)$ \\
$\mathrm{Ln}\left(\mathrm{T}_{\mathrm{GDP}}\right)(-2)$ & 1.956 & 0.696 & 2.808 & $(0.003)$ \\
$\mathrm{Ln}\left(\mathrm{W}_{\mathrm{GDP}}\right)$ & -2.763 & 0.767 & 3.603 & $\mathrm{DW}=2.284$ \\
$\mathrm{R}^{2}=0.97$ & $\mathrm{~F}(\mathrm{p})=87.674(0.00)$ & & & \\
\hline Long-term equation calculated with ARDL & & $2.461^{*}$ & -0.743 & \\
\hline $\mathrm{C}$ & 23.753 & 9.651 & $4.681^{*}$ & $-3.091^{*}$ \\
$\mathrm{Ln}(\mathrm{RER})$ & -0.327 & 0.440 & 1.071 & \\
$\operatorname{Ln}\left(\mathrm{T}_{\mathrm{GDP}}\right)$ & 5.016 & 1.494 & & \\
$\mathrm{Ln}\left(\mathrm{W}_{\mathrm{GDP}}\right)$ & -4.621 & & & \\
\hline
\end{tabular}

Note. $(*)$, it expresses $5 \%$ level of significance.

Equation of ARDL $(1,2,2,0)$ is created like this according to conclusion of ARDL model and calculated long-term coefficient in Table 3:

$$
\mathrm{Ln}(\mathrm{M}-\mathrm{X})=23.753+5.016 \mathrm{Ln}\left(\mathrm{T}_{\mathrm{GDP}}\right)-4.621 \mathrm{Ln}\left(\mathrm{W}_{\mathrm{GDP}}\right)-0.327 \mathrm{Ln}(\mathrm{RER})
$$

As seen in Table 3, in long-term equation, ratio of Turkey and GDP of world is found meaningful statistically, value of real exchange rate is found meaningless. It is observed that increasing one unit GDP ratio of world decreases 4.62 units foreign trade deficit. If GDP ratio of world increases, it will be seen an increasing export as well; despite the fact that import will decrease so it proves that there is a negative relationship between two variables. However, it can be said that there is positive relationship between GDP ratio of Turkey and foreign trade deficit. Namely, an increasing GDP ratio of Turkey causes increasing ratio of import and decreasing ratio of export. Another conclusion derived from Table 3 is that if GDP ratio of Turkey is greater than GDP ratio of world and marginal import trend of Turkey is greater than marginal import trend of world, it can be interpreted a disadvantage situation for Turkey. 
Having high fixed term coefficient shows that another factor except for independent variables taking part in model is effective on foreign trade deficit.

\section{Short-Term Relationship}

Moreover with deviation correction model based on ARDL bounding test approximation, it has searched short-term relationship between variables. The error term obtained from the long-term relationship of the value of "ECM $(t-1)$ " given in Table 4 shows a delayed value of the series. This coefficient shows how much of the imbalance in the short term will come into balance in the next period. Model used in short term is being as used in long term ARDL $(1,2,2,0)$ model.

Table 4

Deviation Correction Model Results Based on ARDL (1, 2, 2, 0) Model

\begin{tabular}{lllll}
\hline Variables & Coefficient & S. D. & $T$-value & $P$-value \\
\hline dLnRER $_{\text {LLnRER }_{1}}$ & 0.793 & 0.273 & 2.897 & $0.010^{*}$ \\
dLnT $_{\mathrm{GDP}}$ & 0.728 & 0.313 & 2.323 & $0.033^{*}$ \\
$\mathrm{dLnT}_{\mathrm{GDP} 1}$ & 6.128 & 0.620 & 0.882 & $0.000^{*}$ \\
$\mathrm{dLnW}_{\mathrm{GDP}}$ & -1.956 & 0.696 & -2.808 & $0.012^{*}$ \\
$\mathrm{ECM}_{(\mathrm{t}-1)}$ & -2.763 & 0.767 & -3.603 & $0.002^{*}$ \\
$\mathrm{R}^{2}=0.96$ & -0.598 & & -3.784 & $0.001^{*}$ \\
\hline
\end{tabular}

Note. $\left({ }^{*}\right)$ it expresses $5 \%$ level of significance.

According to deviation correction model results in Table 4, deviation correction coefficient expressed by " $E C M_{(t-1)}$ " is determined as -0.59 . Being deviation correction coefficient between -1 and 0 is a meaningful situation. $E C M_{(t-1)}$ value expresses that $60 \%$ of imbalance in short term will smooth in next term (next year).

The independent variables in model which are statistically meaningful show that these variables have meaningful effect on foreign trade deficit in short term. It is seen that GDP of Turkey has positive effects in long term but negative effects in short time; at the same time real exchange rate coefficient is meaningless in long term but meaningful and positive in short term. It can be interpreted that increasing real exchange rate (domestic currency losing value) has caused positive effect on foreign trade deficit.

Finally CUSUM and CUSUMQ tests suggested by Brown, Durbin, and Evans (1975) are used for evaluating long-term coefficient stability in model. CUSUM test is based on cumulative deviation terms related with $n$ observation cluster and significance of test shows stability of estimated coefficients (Altınbaş \& Çetin, 2008). Figure 1 shows results of CUSUM and CUSUMQ tests.

As shown in Figure 1, the coefficients of the long-run foreign trade model are stable. However, in the CUSUMQ test it appears that the critical period is close in the first period. This proximity seems to be temporary and stays in the statistical limits of CUSUMQ in long term. 

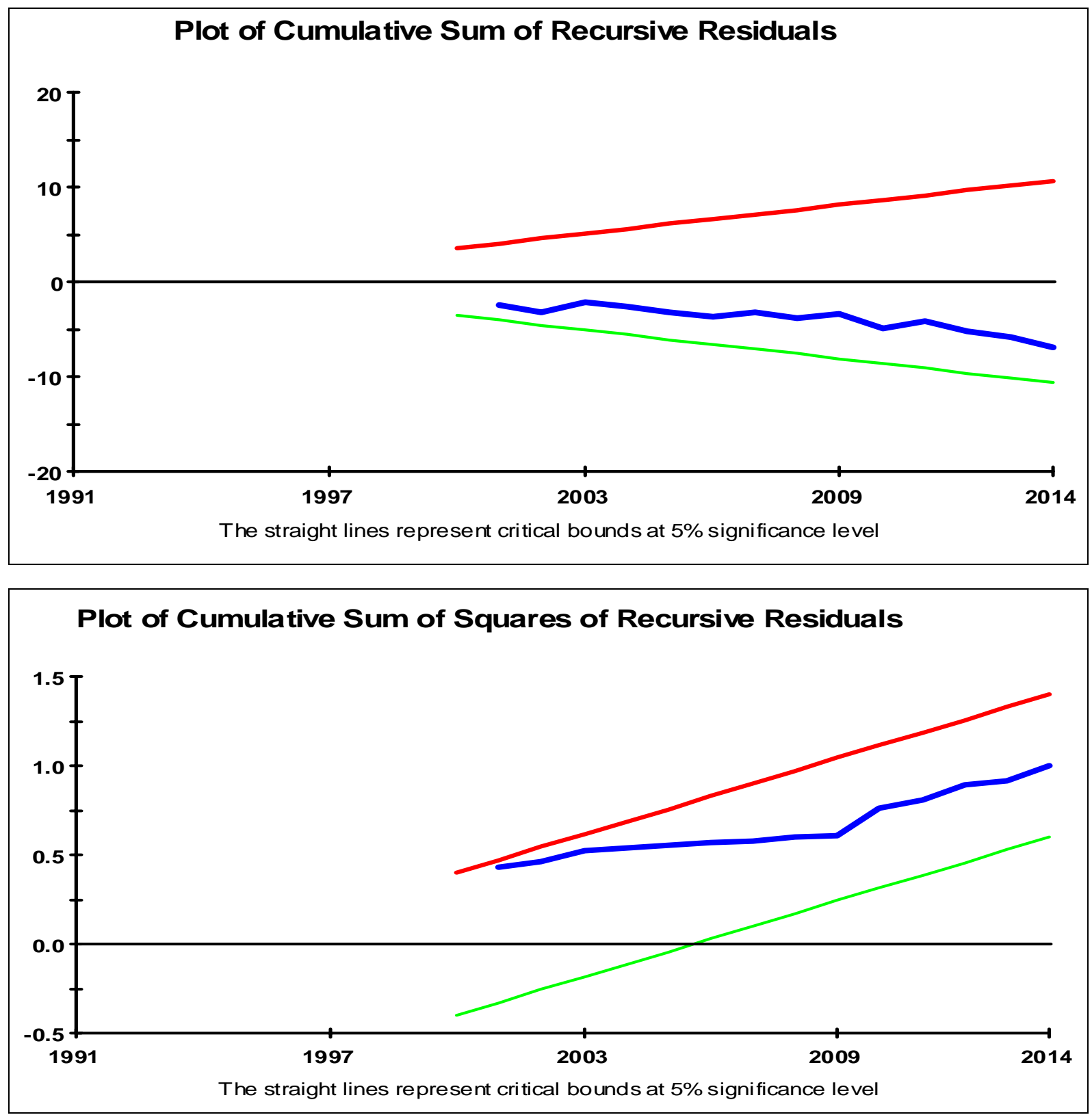

Figure 1. Long-term CUSUM and CUSUMQ test statistic results.

\section{Conclusion}

The purpose in this study is to examine the effects of real exchange rate changes on the foreign trade deficit and test the validity of the J curve hypothesis for the Turkish economy. In the study, annual data for the period of 1989-2014 and ARDL Boundary Test of time series methods were used. As a result, the real exchange rate variable for the Turkish economy is statistically insignificant. By this result, the existence of a foreign trade structure has begun to become increasingly independent in the Turkish economy. Because of this result, real exchange rates don't control movements of goods and services. Capital movements are more dominant than goods and services movements in this context. Thus, the $\mathrm{J}$ curve hypothesis is not valid for the Turkish economy by these results. Because, in order for the $\mathrm{J}$ curve to be valid, it is first necessary to have a 
high rate of influence of exchange rate on exports and imports in the short term. At the same time, exports should be affected negatively in the short term and exports should increase in the long term as a result of the increase in the real exchange rate (devaluation).

It is concluded that an increase in the world GDP value of the variables included in the model is the effect of the foreign trade deficit of Turkey in reducing term. The statistical significance is also reached as well. In this case, an increase in world GDP value will be reason to increase for the value of Turkish exports. Likewise, an increase in GDP of Turkey will be a mitigating factor in foreign trade deficit of Turkey. In addition, the coefficient obtained is statistically significant as well. In short, the coefficient obtained for Turkey and the world's GDP value is in parallel with the theory both statistically and economically.

\section{References}

Akbostanc1, E. (2004). Dynamics of the trade balance: The Turkish J-curve. Emerging Markets Finance and Trade, 40(5), 57-73.

Aktaş, C. (2010). Türkiye'de reel döviz kuru ile ihracat ve ithalat arasındaki ilişkinin VAR tekniğiyle analizi. Uluslararası Yönetim İktisat ve İşletme Dergisi, 6(11), 123-140.

Altınbaş, H., \& Çetin, R. (2008). Türkiye'de dış ticaret belgesi belirleyicilerinin sınır testi yaklaşımıyla öngörülmesi: 1989-2005. Ankara Üniversitesi SBF Dergisi, 63(4), 29-64.

Aral, A. (2015). Türkiye'de döviz kuru ve diş ticaret ilişkisi: 1992-2013 dönemi eşbütünleşme analizi.

Arize, A. C. (1994). Cointegration test of a long-run relation between the real effective exchange rate and the trade balance. International Economic Journal, 8(3), 1-9.

Baek, J. (2007). The J-curve effect and the US-Canada forest products trade. Journal of Forest Economics, 13(4), $245-258$.

Bahmani-Oskooee, M., \& Alse, J. (1994). Short-run versus long-run effects of devaluation: Error-correction modeling and cointegration. Eastern Economic Journal, 20(4), 453-464.

Bahmani-Oskooee, M., \& Brooks, T. J. (1999). Bilateral J-curve between US and her trading partners. Review of World Economics, 135(1), 156-165.

Brada, J. C., Kutan, A. M., \& Zhou, S. (2005). The exchange rate and the balance of trade: The Turkish experience. The Journal of Development Studies, 33(5), 675-692.

Brown, R. L., Durbin, J., \& Evans, J. M. (1975). Techniques for testing the constancy of regression relations overtime. Journal of the Royal Statistical Society, 37(13), 149-163.

Caves, R. E., Jeffrey A. F., \& Ronald, W. J. (2007). World trade and payments, Tenth Edition. USA: Pearson Addison Wesley.

Coşkun, M., \& Taylan, A. S. (2009). Döviz kurlarındaki değişim ihracat ve ithalat hacmini etkiler mi? 1999-2007 Türkiye örneği. Mufad Dergisi, 42, 157-168.

Dickey, D. A., \& Fuller, W. A. (1979). Distribution of the estimators for autoregressive time series with a unit root. Journal of the American Statistical Association, 74(366), 427-431.

Felderer, B., \& Homburg, S. (2010). Makro iktisat ve yeni makro iktisat. Çevirenler: Osman Aydoğuş, N. Oğuzhan Altay, Ankara: Efil Yayınevi.

Gujarati, D. N. (2004). Basic econometrics. New York: McGraw Hill.

Hsing, H. M. (2005). Re-examination of J-curve effect for Japan, Korea and Taiwan. Japan and the World Economy, 17(1), 43-58.

Johansen, S. (1988). Statistical analysis of cointegration vectors. Journal of Economic Dynamics and Control, 12(2), 231-254.

Karaçor, Z., \& Gerçekler, M. (2012). Reel döviz kuru ve dış ticaret ilişkisi: Türkiye örneği (2003-2010). Selçuk Üniversitesi İIBF Sosyal ve Ekonomik Araştırmalar Dergisi, 23, 289-312.

Karagöz, M., \& Doğan, Ç. (2005). Döviz kuru dış ticaret ilişkisi: Türkiye örneği. Fırat Üniversitesi Sosyal Bilimler Dergisi, 15(2), 219-228.

Karamelikli, H. (2016). Türkiye'nin diş ticaret dengesinde J-Eğrisi etkisi. İnsan ve Toplum Bilimleri Araştırmaları Dergisi, 5(3), 389-402.

Kasman, A., \& Kasman, S. (2005). Exchange rate uncertainty in Turkey and its impact on export volume. METU Studies in Development, 32(1), 41. 
Kızıltan, A., \& Ciğerlioğlu, O. (2008). Türkiye'de reel döviz kuru değişmelerinin ihracat ve ithalata etkisi. EKEV Akademi Dergisi, $36,49-50$.

Köse, N., Ay, A., \& Topallı, N. (2008). Döviz kuru oynaklığının ihracata etkisi: Türkiye örneği (1995-2008). Gazi Üniversitesi İktisadi ve İdari Bilimler Fakültesi Dergisi, 10(2), 25- 45.

Kösekahyaoğlu, L., \& Kemeç, A. (2015). J eğrisi analizi ve Türkiye üzerine bir uygulama. Uluslararası İktisadi ve İdari Bilimler Dergisi, 1(2), 1-29.

Kwiatkowski, D., Phillips, P. C. B., Schmidt, P., \& Shin, Y. (1992). Testing the null hypothesis of stationarity against the alternative of a unit root. Journal of Econometrics, 54, 159-178.

Mishkin, F. S. (2004). The economics of money, banking, and financial markets. USA: Pearson Addison Wesley.

Narayan, P. K. (2004). New Zealand's trade balance: Evidence of the J-curve and granger causality. Applied Economics Letters, $11(6), 351-354$.

Onafowora, O. (2003). Exchange rate and trade balance in East Asia: Is there a J-curve. Economics Bulletin, 5(18), 1-13.

Pesaran, M. H., Shin, Y., \& Smith, R. J. (2001). Bounds testing approaches to the analysis of level relationships. Journal of Applied Econometrics, 16(3), 289-326.

Phillips, P. C., \& Perron, P. (1988). Testing for a unit root in time series regression. Biometrika, 75(2), 335-346.

Rose A. K., \& Yellen, J. L. (1989). Is there a J-curve? Journal of Monetary Economics, 24, 53-68.

Sivri, U., \& Usta, C. (2001). Reel döviz kuru, ihracat ve ithalat arasındaki ilişki. Uludă̆ Üniversitesi İIBF Dergisi, 19(4), 1-9.

Terzi, H., \& Zengin, A. (1999). Kur politikasının dış ticaret dengesini sağlamadaki etkinliği: Türkiye uygulaması. Ekonomik Yaklaşım, 10(33), 48-65.

Uzunoğlu, H., \& Alptekin, E. (2009). Ekonomi döviz kurunun dış ticaret kompozisyonu üzerindeki etkileri. AR\&GE Bülten.

Wilson, P. (2001). Exchange rates and the trade balance for dynamic Asian economies: Does the J-curve exist for Singapore, Malaysia and Korea? Open Economies Review, 12(4), 389-413.

Yamak, R., \& Korkmaz, A. (2005). Reel döviz kuru ve dış ticaret dengesi ilişkisi. Ekonometri ve İstatistik Dergisi, 2 , 11-29.

Yılmaz, Ö., \& Kaya, V. (2007). İhracat, ithalat ve reel döviz kuru ilişkisi: Türkiye için bir VAR modeli. İktisat İsletme ve Finans, 22(250), 69-84.

Zengin, A., \& Terzi, H. (1995). Türkiye'de kur politikası, ithalat, ihracat ve dış ticaret dengesi ilişkisinin ekonometrik analizi. Gazi Üniversitesi IIBF Dergisi, 11(1-2), 247-266.

Zhang, Z. (1996). The exchange value of the Renminbi and China's balance of trade: An empirical study. NBER Working Papers Series, 5771 . 